\title{
LATE-GLACIAL CWM GLACIERS IN WALES
}

\author{
By BRIAN SEDDON \\ (Sub-department of Quaternary Kesearch, Cambridge)
}

\begin{abstract}
Summary. The evidence for the existence of small glaciers in the cwms of the Caernarvonshire mountains during the Late-glacial Period is presented, and by an analysis of their distribution some of the factors responsible for the Late-glacial Period is presented, and py an werimaty protection from insolation, drifting of snow into the cirques by wind and the distribution of precipitation.
\end{abstract}

Zusammenfassung. Der Beweis von der Existenz kleiner Gletscher in den Karen des Caernarvonshire Gebirges in der Spätglazialer Periode wird dargelegt, und durch eine Analyse ihrer Anordnung werden einige der Faktoren, in der Spätglazialer Periode wird dargelegt, und durch eine Analyse ihrer Ainie Schutz vor Besonnung, Schneetreiben in die Kare durch Wind und die Verbreitung von Niederschlägen.

\section{INTRODUCTION}

The closing phase of the last glacierization in North Wales manifested itself in the formation of glaciers which generally took the form of ice beds resting entirely within the cwms (cirques) which are very strikingly developed in the mountains of Caernarvonshire. These cwm glaciers may have been the last stages of retreat of the valley glaciers or they may have formed in a period of climatic deterioration which followed the primary amelioration known as the Allerød Period and ended $c$. 10,000 years ago. The moraines of this region probably criginated in both of these ways as some of them are known to date from the Pre-Allerød phase and others from the Post-Allerød. Organic deposits at widely scattered sites in north-west Europe ${ }^{1}$ have yielded by the technique of pollen analysis detailed information about the vegetation and climate of that temporary amelioration and the less favourable conditions which followed, and which also immediately preceded it. From such investigations a precise definition of this tripartite period has become possible and it is known as the Late-glacial Period. It is in this strict sense that the term is applied in the following discussion, with particular reference to the cooler Post-Allerød and immediately Pre-Allerød Periods.

\section{DisTRIBUTION}

The area considered in this study is bounded by the Conway Valley to the east, by the coast of the Menai Straits to the north, by the valleys of Nant Gwynant and Nant y Gwrhyd to the south, and by the Caernarvon-Portmadoc road to the west. Within it are four mountain masses separated by glacial through-valleys.

The most westerly group of mountains lies between the Caernarvon-Portmadoc road and the Cwellyn Valley, i.e. Nant y Bettws and Nant Colwyn, and includes the Nantlle Ridge, the Moel Hebog Ridge and the isolated Mynydd Mawr. This will be referred to as the West Snowdon Group. The cwm moraines observed within this group include one in Cwm Silin, two in Cwm y Ffynnon and one in Cwm Du. None occur in cwms on the Moel Hebog Ridge.

The second group is the Snowdon Group consisting of the spurs radiating from the summit of Snowdon itself with their contained cwms, viz. Cwm Glas, Cwm Dyli, Cwm Tregalen, Cwm Clogwyn and Cwm D'ur Arddu, and also the long north-western ridge of hills bearing Cwm Cynghorion and Cwm Dwythwch.

The third group, further east again, is the Glyder Group which has a magnificent series of cwms hanging above Nant Ffrancon, namely from north to south Cwm Ceunant, Cwm Graianog, Cwm Perfedd, Cwm Goch, Cwm Cywion, Cwm Clyd and Cwm Idwal, with Marchlyn Mawr and Marchlyn Bach in the extreme north and Cwm Tryfan in the east.

The most easterly block is the Carnedd Group on which cwm moraines have been observed in Cwm Ffynnon Lloer, Cwm Melynllyn, Cwm Dulyn, Cwm Anafon, Cwm Ffynnon Caseg and Cwm Llafar. 


\section{LATE-GLACIAL CWM GLACIERS IN WALES}

All the cwm moraines in the area are shown on the map (Fig. I, p. 97), and each is numbered and referred to in the table where the name, altitude and aspect are given. The altitude figures are taken from the one inch O.S. map and for this purpose an approximation to the nearest $100 \mathrm{ft}$. ( $30 \mathrm{~m}$.) contour is used where the height of the lake is not stated. The aspect of the cwm glaciers is given as the direction at right-angles to the line of the end moraine. All the sites have been visited by the author and in the case of the series of cwms above Nant Ffrancon (Glyder Group) the altitudes of the moraines were determined by altimeter and the aspects by prismatic compass. The aspect of the cwm glacier does not necessarily coincide with the axis of the cwm since the majority of the cwms were probably excavated long before their last occupation during the Late-glacial Period when the moraines under consideration were deposited. In some cases the end moraine is not situated on the lip of the cwm but lies some distance back on the floor of the cwm, e.g. the inner one of the Cwm Idwal moraines (No. 24a on the map).

\section{The Diagrams}

The data presented in the table have been used to construct the polar diagrams (Fig. 2, p. 97) which illustrate the altitudinal distribution and orientation of the cwm glaciers on each of the mountain groups. On the diagrams the radii are the points of the compass representing the aspect of the glaciers and the concentric circles represent height above sea level of the moraines. From these two characteristics a position can be plotted for every moraine.

The most obvious feature of all four diagrams is the concentration of the moraines in the north-eastern sector which indicates the preponderance of glaciers of north-eastern aspect. Helland 2 in describing Jotunheimen, noted that 24 of 37 cirques occurred in the north-westnorth-east sector and recognized the importance of solar radiation in producing such a distribution. Lewis ${ }^{3}$ has shown the same thing in a sample of 44 cirques from British mountains using a wind-rose type of diagram. Similarly the occurrence of cirques predominantly on the north and east of mountain groups has been recorded inter alia in the Comeragh Mountains ${ }^{4}$, Mount Leinster and Blackstairs Mountain ${ }^{5}$, Wicklows 6,7 and in the Snowdon District ${ }^{8}$.

On the composite diagram (Fig. 2d) all the moraines are plotted, using distinctive symbols for the moraines of each mountain block, and the lowest moraines of various aspect within each group are connected by a line. The line joining the lowest moraines of the Snowdon and West Snowdon Groups completely surrounds and contains those of the two more easterly groups. Similarly the line joining the lowest moraines of the Glyder Group encloses that of the Carnedd Group with a single exception on the east radius.

The course of the lines linking the moraines of lowest altitude on all radii of all three groups traces the form of a horseshoe. That is, in any given group, commencing at the point farthest away from the centre of the polar diagram which in every case lies on the north-east radius, the curve gradually flattens and approaches the centre as it is followed in either direction from this point. The absence of moraines of south-westerly aspect makes it impossible to draw these curves across that sector of the diagrams. However, it is apparent from the existing data that, e.g. on the Snowdon and West Snowdon Groups (Fig. 2a), the cwm glaciers of north-easterly aspect descended lowest of all and that those cwm glaciers facing between north-east and north-west and likewise those facing between north-east and south-east deposited their moraines at progressively higher altitudes. The pattern is repeated more or less precisely on the Glyder and Carnedd Groups. The heights of the lowest moraines of all aspects on each of the three groups when plotted lie on an inclined plane and an attempt has been made to represent this in Fig. 3, p. 97. Since it has already been deduced from the composite polar diagram (Fig. 2d) that the majority of the Carnedd moraines lie at higher altitudes than those of the Glyders, and that these lie at higher altitudes than the Snowdon and West Snowdon Group moraines this plotted distribution shows a progressive elevation from one mountain group to the next taken in order from
south-west to north-east. 
Fig. 3 is a three-dimensional diagrammatic representation of the lower limit of moraines in each group and the spatial relations of the three groups. The elliptical lines enclosing the shaded areas include all the cwm moraines on each mountain mass, the ordinates representing altitude, distance along the south-west to north-east section as, abscissae, and aspect being shown as the third dimension. The portion of the ellipses enclosing the unshaded areas are produced by extrapolation since no moraines of south-westerly aspects exist in the region. The curves were constructed by taking an average of the altitudes of the cwm moraines of south-easterly and northwesterly aspects in each group and plotting this value as the ordinates, e.g. for the Snowdon and West Snowdon Groups $1700 \mathrm{ft}$. (520 m.), for the Glyder Group $2000 \mathrm{ft}$. (610 m.), for the Carnedd Group $2200 \mathrm{ft}$. $(670 \mathrm{~m}$.). South-east and north-west are represented isodiametrically, being in a plane at right-angles to the paper. Similarly, the altitude of the lowest moraine of north-east aspect was plotted, this direction lying in the plane of the paper. It is, in fact, an attempt to portray the polar diagrams as they would appear if the centre of each were pushed up to form a cone on which the concentric rings would be contours.

\section{Discussion}

From the factual observations described, it is considered that the Late-glacial cwm glaciers were subject to the consistent operation of a number of climatic factors.

The orientation of a large number of the glaciers to a northerly or north-easterly aspect implies a definite relationship to insolation. In this position they would be subject to a minimum of ablation owing to the shading afforded by the steep rock walls of most of these cwms, for example Cwm Du and and Cwm Llafar are particularly illustrative.

It has been shown in Lofoten 9,10 that drifting by wind from exposed areas above the snowline takes place and that snow accumulates more on the leeward sides of mountains. The fact that the majority of the cwm glaciers were situated to the north and east of the areas of high land (Fig. I), suggests the influence of snow-drifting under meteorological conditions not unlike those of the present with respect to prevailing wind direction. It would appear, therefore, that the prevailing winds had been south-westerly, causing drifting from exposed summit plateaux and broad cols.

It has been shown on the composite diagram (Fig. 2d) that for any given aspect the cwm glaciers on the western group of mountains, including the Snowdon and West Snowdon Groups, reached lower altitudes than those cwm glaciers with the same aspect on the Glyder Group and that those of the Glyder Group reached lower altitudes in any given aspect than those of the Carneddau with only one exception. For example, on the north-eastern radius of the diagram the lowest moraine on the Snowdon Group lies at $900 \mathrm{ft}$. $(275 \mathrm{~m}$.), on the Glyder Group the lowest is at $1300 \mathrm{ft}$. $(395 \mathrm{~m}$.), and on the Carneddau at $1600 \mathrm{ft}$. $(490 \mathrm{~m}$.). The corresponding figures for the northern radius are 1 r $00 \mathrm{ft}$. $(335 \mathrm{~m}$.) for the Snowdon Group, I $800 \mathrm{ft}$. $(550 \mathrm{~m}$.) for the Glyders, and $2100 \mathrm{ft}$. $(640 \mathrm{~m}$.) for the Carneddau. The average altitude of the moraines of the Snowdon and West Snowdon Group calculated from the fifteen cwms listed in the Table I (p. 98$)$ is $1330 \mathrm{ft}$. $(405 \mathrm{~m}$.), for the Glyder Group the figure (calculated from eleven listed cwms) is $1720 \mathrm{ft} .(525 \mathrm{~m}$.), and for the Carneddau (based on seven cwms) it is $1985 \mathrm{ft}$. (605 m.).

An explanation of the progressive elevation across the mountain groups from south-west to north-east of the altitude-aspect distributions (Fig. 3) is not possible in terms of the area under névé on each mountain mass. The area of high land on the Carneddau is much greater than that on the Glyders and the latter have a greater area of high land than the Snowdon Group. The area of land above the $2000 \mathrm{ft}$. (6ro m.) contour on the Carnedd Group is $34.75 \mathrm{~km} .{ }^{2}$, on the Glyder Group $18.25 \mathrm{~km} .^{2}$, and on the Snowdon and West Snowdon Groups combined $1 \mathrm{r} \cdot 0 \mathrm{~km} .{ }^{2}$. If the area of névé on the three mountain groups was produced under an annual precipitation uniformly distributed over the area, we might expect the cwm glaciers of the Carneddau to have been the largest and to have descended to the lowest altitudes. However, since this is emphatically not the case the distribution of precipitation over the area cannot have been uniform. The western 


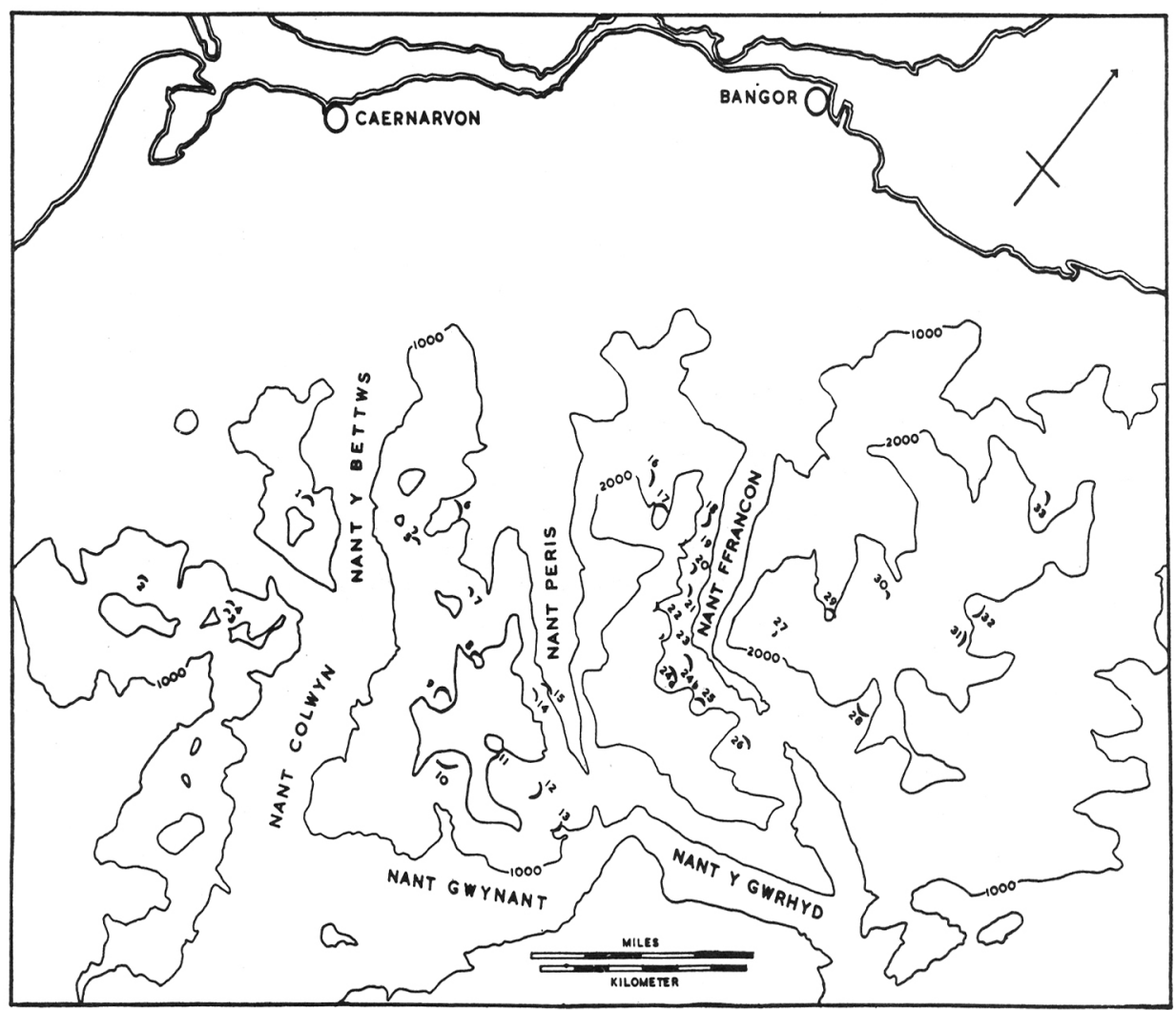

Fig. I. Map of North Caernarvonshire with Late-glacial cwm moraines inserted and numbered. The $1000 \mathrm{ft}$. (305 m.) and $2000 \mathrm{ft}$. contours are shown
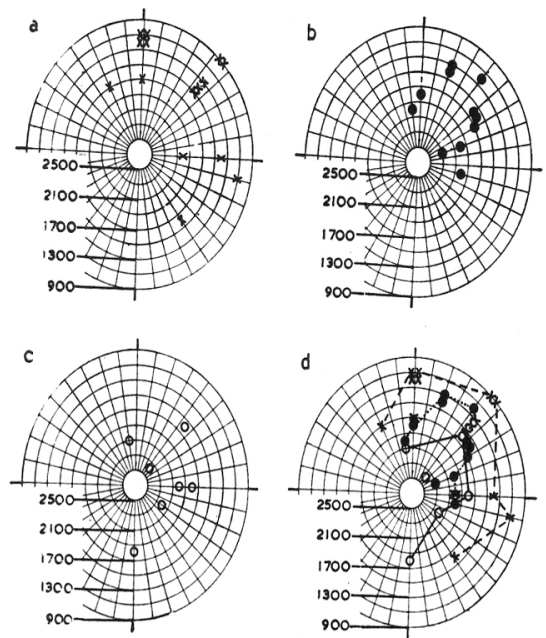

Fig. 2 (left). The polar diagrams show the relation between altitude in feet (concentric circles) and aspect (radii) in the distribution of the moraines, (a) on the Snowdon and West Snowdon Groups, (b) on the Glyder Group, (c) on the Carnedd Group. Diagram (d) shows all groups together. The lines connect the moraines of lowest altitude of all aspects on each of the three groups. The cardinal points of the compass are shown by lines at the edge of the diagrams, Grid North at top

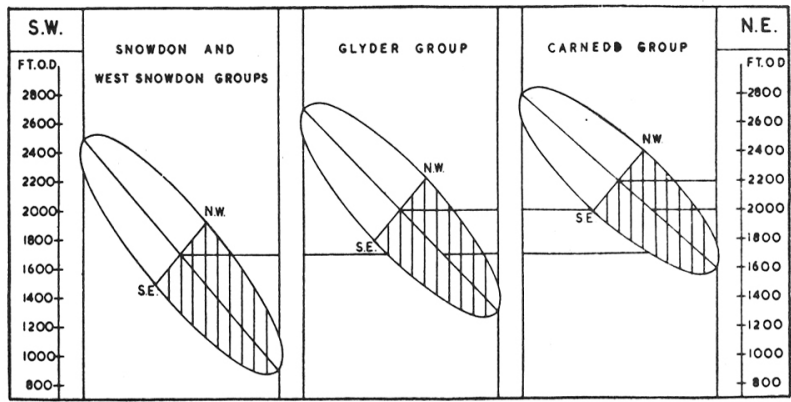

Fig. 3. The plane of the paper represents a S.W.-N.E. section across Caernarvonshire. The altitude and aspect relations of the cwm moraines on the three mountain groups are represented isodiametrically. The lowest moraines on each group are contained within the shaded portion of the ellipse 
mountains must have received heavier precipitation than those farther east, Snowdon etc. receiving most, the Carneddau least, and the Glyders an intermediate amount. The precipitation gradient at the present day may be illustrated by average annual rainfall figures taken between I9Io and I9I7 inclusive ${ }^{11}$. At Pen y Gwryd, in the lee of Snowdon at $913 \mathrm{ft}$. $(275 \mathrm{~m}$.) the average over eight years was 135.14 in. $(3430 \mathrm{~mm}$.), at Llyn Ogwen in the lee of the Glyders at $1004 \mathrm{ft}$. $(305 \mathrm{~m}$.) the average for two years was $\mathrm{I}_{2} \mathrm{I} \cdot \mathrm{I}_{5} \mathrm{in}$. (3060 mm.), and at Llyn Eigiau in the lee of the Carneddau at $1245 \mathrm{ft}$. $(380 \mathrm{~m}$.) the average over seven years was $83.59 \mathrm{in}$. (2120 mm.). It is not contended that the actual figures have any significance with regard to the Late-glacial: they are quoted purely as an illustration of the parallelism of precipitation distribution then and now. It is concluded that the size of the glaciers was approximately proportional to the amount of precipitation which fell within their respective areas of accumulation. This evidence ascribed to precipitation also enforces the conclusion already reached that the meteorological regime of the Late-glacial Period was not greatly different from that of the present day.

The factors discussed here are all considered solely in relation to the formation and maintenance of cwm glaciers in the Late-glacial Period and although many or all of these factors may have been operative in the formation of the cwms themselves, no implications in that context are intended. The pre-existence of the cwms prior to this period determined the general distribution of the last remnants of glaciers, but the Late-glacial cwm glaciers did not in every case conform either in size or aspect to these sites.

\section{ACKNOWLEDGEMENTS}

Grateful acknowledgement is made to the Nature Conservancy for a Post-graduate Research Studentship during the tenancy of which the work was carried out, and to Dr. J. J. Donner, Dr. J. W. Glen, Dr. D. Walker and Dr. R. G. West for helpful criticism and advice.

MS. received I4 Fanuary 1957

\section{REFER E N CES}

1. Gross, H. Das Alleröd-Interstadial als Leithorizont der letzten Vereisung in Europa und Amerika. Eiszeitalter und Gegenwart, Bd. 4/5, 1954, p. 189-209.

2. Helland, A. Om Botner og Saekkedale samt deres betydning for theorier om dalenes dannelse. Geologiska Föreningens $i$ Stockholm Förhandlingar, Bd. 2, 1875, p. 286 and 342.

3. Lewis, W. V. A meltwater hypothesis of glacial erosion. Geological Magazine, Vol. 75, 1938, p. 249.

4. Reed, F. R. Cowper. Notes on the corries of the Comeragh Mountains, County Waterford. Geological Magazine, Decade 5, Vol. 3, 1906, p. I 54 and 227.

5. Farrington, A. The local glaciers of Mount Leinster and Blackstairs Mountain. Proceedings of the Royal Irish Academy, Vol. 45 B, No. 3, 1938 .

6. Charlesworth, J. K. The glacial retreat from central and southern Ireland. Quarterly Journal of the Geological Society of London, Vol. 84, 1928, p. 293.

7. Farrington, A. The glaciation of the Wicklow Mountains. Proceedings of the Royal Irish Academy, Vol. 42 B, No. 7, I 934 .

8. Davis, W. M. Glacial erosion in North Wales. Quarterly Journal of the Geological Society of London, Vol. 65, 1909 , p. 281 .

9. Enquist, Fredrik. Der Einfluss des Windes auf die Verteilung der Gletscher. Bulletin of the Geological Institution of the University of Upsala, Vol. $14,1917$.

10. Enquist, Fredrik. Die glaziale Entwicklungsgeschichte Nordwest-skandinaviens. Sveriges Geologiska Undersökning. Avhandlingar och Uppsatser. Ser. C, No. 285, 1918.

1 1. Carr, H. R. C., and Lister, G. A. The mountains of Snowdonia. London, Crosby Lockwood, 1948, p. 308.

\section{Explanation OF TABLE}

TABLE I

The table lists all the moraines recorded under the names of the cwms in which they occur. They are numbered to facilitate reference to the map (Fig. I), their altitudes are given in feet and metres and the aspect of the glacier is given in degrees. The asterisk indicates those moraines whose altitude was determined by altimeter and aspect by prismatic compass (figures corrected to True North). 
Group

WeSt SNOWDON

SNOWDON

GLYDER

CarnedD
TABLE I (cont.)

\section{Name of Cum}

\begin{tabular}{|c|c|c|c|}
\hline & \multicolumn{2}{|c|}{ Altitude } & Aspect \\
\hline & Feet & Metres & \\
\hline$\cdot$ & . $\quad 1200$ & 365 & 6 \\
\hline . & $\because \quad 1100$ & 335 & 0 \\
\hline$\cdot$ & $\therefore \quad 1200$ & 365 & $\circ$ \\
\hline$\cdots$ & $\cdots \quad 1100$ & 335 & 0 \\
\hline$\cdots$ & 1300 & 395 & 45 \\
\hline$\cdots$ & 900 & 275 & 45 \\
\hline$\cdots$ & $\ldots \quad 1500$ & 455 & 45 \\
\hline . & $\ldots \quad 1700$ & 520 & 0 \\
\hline$\cdots$ & .. 1700 & 520 & 320 \\
\hline$\cdots$ & .. 1600 & 490 & 140 \\
\hline$\because$ & . 2000 & 610 & 90 \\
\hline$\cdots$ & .. 1400 & 425 & 90 \\
\hline$\cdot$ & .. 1000 & 305 & 100 \\
\hline . & .. 1400 & 425 & 45 \\
\hline . & 900 & 275 & 45 \\
\hline * & .. 1600 & 490 & 50 \\
\hline . & . 2000 & 610 & 350 \\
\hline . & .. 1240 & 380 & 40 \\
\hline & .. $\quad 1970$ & 600 & $90-100$ \\
\hline & $\ldots \quad 1760$ & 540 & $55-65$ \\
\hline & $\ldots \quad 1640$ & 500 & $50-55$ \\
\hline . & . $\quad 2050$ & 625 & $70-75$ \\
\hline${ }^{\circ}$ & . $\quad 2300$ & 700 & 70 \\
\hline 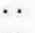 & .. $\quad 1280$ & 390 & $15-20$ \\
\hline$\cdot$ & $\begin{array}{l}\ldots \\
\ldots\end{array}$ & 380 & $15-20$ \\
\hline & $\ldots \quad 1800$ & 550 & $\circ$ \\
\hline 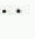 & .. $\quad 1400$ & 425 & 20 \\
\hline . & . $\quad 2200$ & 670 & 120 \\
\hline . & .. $\quad 1800$ & 550 & 180 \\
\hline . & .. 2100 & 640 & 350 \\
\hline - & . $\quad 2400$ & 730 & 45 \\
\hline & . $\quad 2100$ & 640 & 90 \\
\hline & 1800 & 550 & 90 \\
\hline & 1600 & 490 & 45 \\
\hline
\end{tabular}

\title{
ICE ACTION ON NEW ENGLAND LAKES
}

\author{
By Lawrence GoldthwatT
}

(Science Department, St. George's School, Newport, R.I., U.S.A.)

\begin{abstract}
Motion produced by ice expansion and by wind-blown ice cakes has modified the shores of lakes in northern New England, U.S.A. Twenty-six lakes have been studied, the processes observed, and measurements

Zusammenfassung. Die durch Ausdehnung von Eis und durch windgewehte Eiskuchen hervorgerufene Bewegung hat die Ufer von Seen in Nord-Neu-England, U.S.A., modifiziert. Sechsundzwanzig Seen wurden untersucht, die Prozesse beobachtet, und Messungen vom Verlauf und Ausmass der Eisaktion gemacht. Schlussfolgerungen
\end{abstract}

\section{INTRODUCTION}

The shores of many lakes are altered by the action of expanding ice cover and wind-blown ice cakes. As far back as 1822 Lee ${ }^{1}$ reported moving rocks in Connecticut. Later many articles have dealt with the origin of ice action features, notably articles by Buckley ${ }^{2}$ and by Gilbert ${ }^{3}$ on Wisconsin, by 'Tyrrell ${ }^{4}$ on northern Canada, and by Hellaakoski ${ }^{5}$ on Finland. Recently Stanley ${ }^{6}$ described the dragging of boulders in the Death Valley region in California by wind-blown ice 